\title{
Molecular prevalence of parvovirus B19 among HIV1-infected patients in Iran
}

\author{
Seyed Jalal Kiani ${ }^{1}$, Davod Javanmard ${ }^{1}$, Hadi Ghaffari ${ }^{1}$, Ahmad Tavakoli ${ }^{1}$, Helya Sadat Mortazavi ${ }^{1}$, \\ Farah Bokharaei-Salim¹, Zahra Bangaleh², Seyed Hamidreza Monavari*1
}

\begin{abstract}
Background: Different outcomes of parvovirus B19 (B19V) infection in immunocompromised patients, including HIV1-infected persons, may be life-threatening. Considering the hematologic disorders associated with B19V infection, this study aimed to investigate the prevalence of B19V infection among HIV1-infected individuals in Iran.

Methods: Serum samples from 100 HIV1-infected patients were analyzed for B19 viral DNA using real-time PCR assay. COBAS TaqMan HIV-1 test was performed for quantitative measurements of HIV-1 RNA in the patients' sera.

Results: Real-time PCR analysis revealed that 10 out of 100 cases $(10 \%)$ were positive for B19V infection. Across various age groups, the B19V infection was more prevalent among patients within the age range of 21-40 years. Higher prevalence of B19V infection was observed among HIV1-infected patients with a viral load of higher than 400 copies $/ \mathrm{mL}$.

Conclusion: Despite limitations, this study may set the stage for further evaluations with larger sample sizes to elucidate the potential role of B19V in hematologic disorders, which may result in exacerbation of the disease in HIV1-infected patients. Moreover, as it has been shown that B19V infection can be treated using intravenous immunoglobulin (IVIG) therapy, available treatments may help improve the quality of life in HIV-infected persons.
\end{abstract}

Keywords: Parvovirus B19, HIV-1, Anemia, AIDS

Conflicts of Interest: None declared

Funding: Iran University of Medical Sciences, Tehran, Iran

\section{*This work has been published under CC BY-NC-SA 1.0 license.}

Copyright $($ Iran University of Medical Sciences

Cite this article as: Kiani SJ, Javanmard D, Ghaffari H, Tavakoli A, Mortazavi HS, Bokharaei-Salim F, Bangaleh Z, Monavari SH. Molecular prevalence of parvovirus B19 among HIV1-infected patients in Iran. Med J Islam Repub Iran. 2018 (15 Nov);32:113. https://doi.org/10.14196/mjiri.32.113

\section{Introduction}

As a member of the Parvoviridae family, Parvovirinae subfamily, and genus erythroparvovirus, primate erythroparvovirus 1 (previously and commonly known as parvovirus B19) is involved in the development of erythema infectiosum (fifth disease), arthralgia, arthritis, hydrops fetalis, and transient aplastic crisis in patients with shortened red cell survival (1-3). The virus spreads mainly through respiratory droplets. Transmission is also possible parenterally by blood transfusions or by infected blood products and vertically from mother to fetus. After acute infection, it has been shown that the viral DNA persists for life in different tissues of the body $(4,5)$.

Corresponding author: Dr Seyed Hamidreza Monavari,monavari.hr@iums.ac.ir

1. Department of Virology, Faculty of Medicine, Iran University of Medical Sciences, Tehran, Iran

2. Core Laboratory, Iran University of Medical Sciences, Tehran, Iran
In immunocompetents, the infection with $\mathrm{B} 19 \mathrm{~V}$ has also been associated with development of aplastic anemia (6, 7). In immunocompromised patients, however, persistent infection with B19V is involved in chronic suppression of bone marrow and chronic anemia, which is called pure red cell anemia. Cancer patients receiving chemotherapy, transplant patients on immunosuppressive drugs, patients with congenital immunodeficiency, and patients with acquired immunodeficiency syndrome (AIDS) are particularly at risk for B19V infection. These patients are incapable of producing neutralizing antibodies to remove the virus, and hence are vulnerable to persistent infection and

$\uparrow$ What is "already known" in this topic:

Parvovirus B19 is involved in the development of hematologic disorders in immunocompromised patients, including HIV1infected patients.

$\rightarrow$ What this article adds:

The prevalence of parvovirus B19 in HIV1-infected patients of this study was $10 \%$, which can result in exacerbation of the disease. 
subsequent anemia $(8,9)$.

HIV-1 infection results in a chronic disease, which is usually characterized by progressive immunodeficiency, a long period of clinical latency, and appearance of opportunistic infections (10-13). It has been shown that anemia is common in up to $80 \%$ of HIV-infected individuals and the percentage increases as the disease advances $(14,15)$. This condition may result from the use of antiviral therapy (typically zidovudine), deficiencies in iron and vitamin B12, opportunistic infections, AIDS-associated malignancies, autoimmune hemolysis, and persistent infection with B19V (16).

Although several studies have suggested the potential involvement of $\mathrm{B} 19 \mathrm{~V}$ persistent infection in the development of chronic anemia in HIV-infected individuals $(17,18)$, this has not yet been confirmed in larger studies $(19,20)$.

Considering the hematologic disorders associated with B19V infection, this study aimed to investigate the prevalence of B19V infection among HIV1-infected individuals referred to hospitals affiliated to Iran University of Medical Sciences in Tehran.

\section{Methods}

\section{Study population}

This cross sectional survey was conducted at Rasul-eAkram and Firouzgar hospitals in Tehran, Iran. A total of 100 HIV1-infected patients were enrolled in this study. These patients were negative for $\mathrm{HBV}$ and $\mathrm{HCV}$ coinfections and had no history of anti-retroviral therapy. Ethical approval for this survey was obtained from the ethical committee of Iran University of Medical Sciences and informed consent was acquired from all participants.

\section{DNA extraction}

Five milliliters of peripheral blood was taken from each patient in sterile EDTA-containing tubes. After serum separation by centrifugation, the sera were stored at -80 ${ }^{\circ} \mathrm{C}$ until use. Viral Nucleic Acid Extraction Kit (Yekta Tajhiz Azma, Iran) was used to extract DNA from $200 \mu \mathrm{L}$ of serum samples according to the manufacturer's instruction. The quality of the extracted DNA was analyzed by a NanoDrop-1000 spectrophotometer (Thermo Scientific, Wilmington, DE, USA) and stored at $-20^{\circ} \mathrm{C}$ for subse- quent analysis.

\section{HIV-1 Viral load}

COBAS TaqMan HIV-1 test (Roche Diagnostics, CA, USA) was performed for quantitative measurements of HIV-1 RNA in the patients' sera according to the manufacturer's instructions. This real-time PCR assay targets one of the most conserved regions of the HIV-1 gag gene. The detection limit of the test is 48 to $10^{7}$ copies $/ \mathrm{mL}$.

\section{Real-time PCR for parvovirus B19}

Serum samples of HIV-1 patients were investigated for B19V DNA detection using a real-time PCR test that amplified a 154-base pair fragment of the NS1 gene, as described previously (21).

Briefly, a total reaction volume of $16 \mu \mathrm{L}$ was prepared with the mixture of $8 \mu \mathrm{l}$ of $2 \mathrm{X}$ qPCR master mix (Yekta Tajhiz Azma, Iran), $0.5 \mu \mathrm{M}$ of forward and reverse primers, $0.2 \mu \mathrm{M}$ probe, $3 \mu \mathrm{L}$ of extracted DNA, and DNase/RNase-free distilled water. Real-time PCR was performed using a Rotor-Gene Q instrument (Qiagen, Germany). Amplification cycles were programmed as follows: an initial denaturation at $95^{\circ} \mathrm{C}$ for 10 minutes, 35 cycles of $95^{\circ} \mathrm{C}$ for 20 seconds, and $62^{\circ} \mathrm{C}$ for 30 seconds.

\section{Statistical analysis}

The B19V positive and B19V negative groups were compared among HIV1-positive patients using either Chisquare test or Fisher's exact test to detect statistical significance. Student-t test was used to compare the mean ages. All analyses were performed using SPSS statistical software (Version 18). Statistical significance was considered as $\mathrm{p} \leq 0.05$.

\section{Results}

In general, 100 participants (all HIV1-positive), with a mean age of $36.58 \pm 13.16$ years (minimum of 2 and maximum of 69 years), participated in this study. Of the participants, $62(62 \%)$ were male and $38(38 \%)$ were female. Furthermore, the mean HIV-1 viral load of participants was $91496.82 \pm 306987.90$, with a range of 61 to 2606796 copies/mL. Demographic characteristics of the B19 positive and negative groups are summarized in Table 1.

In this study, the real-time PCR analyses revealed that

Table 1. Demographic characteristics of the study participants

\begin{tabular}{|c|c|c|c|}
\hline & B19 positive $(\mathrm{N}=10)$ & B19 negative $(\mathrm{N}=90)$ & \\
\hline & $\mathrm{N}(\%)$ & $\mathrm{N}(\%)$ & $\mathrm{p}$ \\
\hline \multicolumn{4}{|l|}{ Gender } \\
\hline Male & $5(0.05)$ & $57(0.57)$ & N.S \\
\hline Female & $5(0.05)$ & $33(0.33)$ & \\
\hline \multicolumn{4}{|l|}{ Age (y) } \\
\hline $0-20$ & $1(0.01)$ & $6(0.06)$ & N.S \\
\hline $21-40$ & $7(0.07)$ & $51(0.51)$ & \\
\hline $41-70$ & $2(0.02)$ & $33(0.33)$ & \\
\hline Mean \pm SD & $32.89 \pm 13.50$ & $36.24 \pm 12.269$ & \\
\hline \multicolumn{4}{|l|}{ HIV viral load } \\
\hline$<20-75$ copies $/ \mathrm{ml}$ & $1(0.01)$ & $24(0.24)$ & N.S \\
\hline 75-200copies/ml & $1(0.01)$ & $1(0.01)$ & \\
\hline $200-400$ copies $/ \mathrm{ml}$ & - & $3(0.03)$ & \\
\hline $400-30000$ copies $/ \mathrm{ml}$ & $4(0.04)$ & $29(0.29)$ & \\
\hline$>30000$ copies $/ \mathrm{ml}$ & $4(0.04)$ & $33(0.33)$ & \\
\hline Mean \pm SD & $50667.78 \pm 56850.764$ & $96981.31 \pm 326256.16$ & \\
\hline
\end{tabular}

N.S: Not Significant 


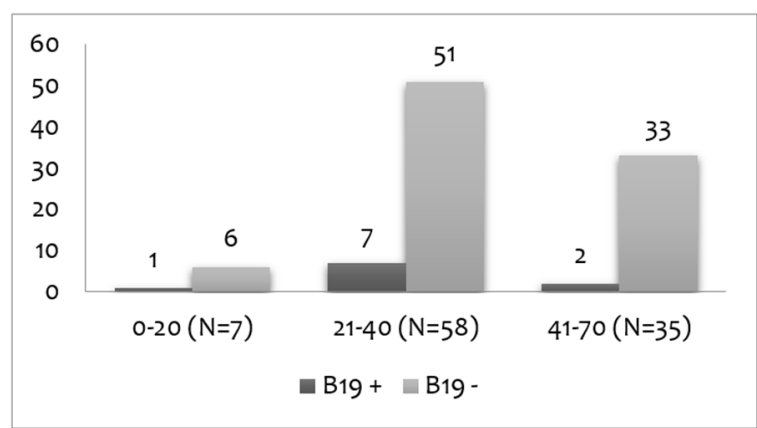

Fig. 1. Age-dependent prevalence of B19 virus in HIV1-infected patients. B19V infection was more prevalent among patients within the age range of $21-40$ years.

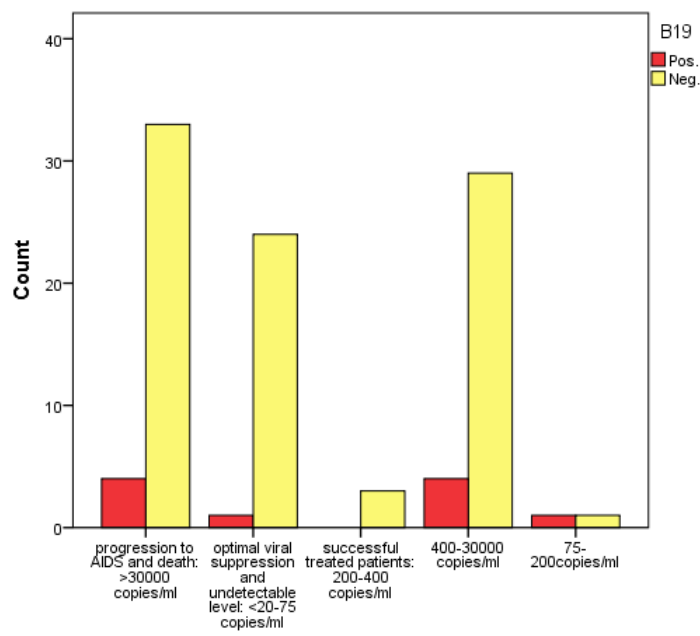

Fig. 2. The prevalence of B19V in HIV1-infected patients with regards to HIV-1 viral load higher prevalence of B19V infection was observed among HIV1-infected patients with a viral load of higher than 400 copies $/ \mathrm{mL}$.

10 out of 100 cases $(10 \%)$ were positive for B19V infection, with a male to female ratio of 1:1. Across various age groups, although not significant, the B19V infection was more prevalent among patients within the age range of 2140 years (Fig. 1). Similarly, higher prevalence of B19V infection was observed among HIV1-infected patients, with a viral load of higher than 400 copies/mL (Fig. 2).

\section{Discussion}

Parvovirus B19, as a widespread virus, has a similar universal infectivity rate in the United States, Europe, and Asia based on the detection of anti-parvovirus IgG antibody in serum samples. B19 infections are seasonal, peaking in late winter, spring, and summer. In temperate climate regions, most infections occur in the spring, and there are small epidemics in every several years (22). The age-specific distribution of $\mathrm{B} 19 \mathrm{~V}$ in Iran is similar to many other countries (23). School-aged children have the highest attack rate of parvovirus and the exposure of nonimmune adults will result in asymptomatic infections, albeit in most cases (24). Valeur-Jensen et al. supported this evidence by stating that having school-aged children in the house is associated with the highest risk of parvovirus infection and they further indicated that as the number of children increases, the risk of infection also increases (25). The infection with parvovirus B19 is more prevalent among women because of their higher exposure to the virus in domestic and occupational activities (26).

In HIV1-infected persons, who were simultaneously infected with $\mathrm{B} 19 \mathrm{~V}$, a decline in hematological values of hemoglobin, white blood cells, and platelets has been reported (27). The involvement of B19V infection in the development of chronic anemia, pure red cell aplasia, and hematological disorders has also been suggested in these patients. Since B19V-induced disorders have been shown to be potentially treatable by intravenous immunoglobulins, identifying chronic B19V infections in immunocompromised patients can have important therapeutic implications $(28,29)$.

Detection of B19V DNA in serum through PCR amplification is the best direct marker available for the diagnosis of B19V infection, especially in immunocompromised patients. In persons infected with HIV, because of their inability to produce neutralizing antibodies (both IgM and IgG) against $\mathrm{B} 19 \mathrm{~V}$, serological methods are not reliable for the diagnosis of the virus $(30,31)$. On the other hand, in highly specialized conditions, the isolation of B19V from cultures of erythroid precursors is restricted to research laboratories (32). Therefore, PCR is the diagnostic method of choice for B19V infection.

In this study, using a real-time PCR assay, B19V nucleic acid was detected in $10 \%$ of persons infected with HIV1. This prevalence was nearly similar to $7.1 \%$ rate in HIV1-infected drug users in Hangzhou (33), 13.1\% rate in HIV1-positive cases in Iran (34), and almost twice in comparison with $4.5 \%$ rate in Sichuan, China (35).

We acknowledge the limitations of this survey, including small sample size, lack of information about serum antibody status against B19V, active or persistent infection with B19V, and HAART therapy-related side-effects in patients. However, these kinds of studies may set the stage for further evaluations with larger sample sizes to elucidate the potential role of $\mathrm{B} 19 \mathrm{~V}$ in hematologic disorders, which may result in exacerbation of the disease in HIV1-infected patients. Moreover, as it has been shown that B19V infection can be treated using IVIG therapy (36), if any significant association is found between B19V-related disorders and HIV1-related conditions, then, available treatments may help improve the quality of life in HIV-infected persons.

\section{Conclusion}

The devastating effects of opportunistic infections on $\mathrm{HIV}$-infected patients in the background of immune suppression necessitates the monitoring and treatment of these complications, especially viral superinfections.

\section{Acknowledgments}

This project was financially supported by Iran University of Medical Sciences (Grant No. 27956).

\section{Conflict of Interests}

The authors declare that they have no competing interests. 


\section{References}

1. Arabzadeh SAM, Alizadeh F, Tavakoli A, Mollaei H, BokharaeiSalim F, Karimi G, et al. Human parvovirus B19 in patients with beta thalassemia major from Tehran, Iran. Blood Res. 2017;52(1):50-54.

2. Snhabai Z, Esghaei M, Keyvani H, Shabani F, Sarmadi F, Mollaie H, et al. Relation between parvovirus B19 infection and fetal mortality and spontaneous abortion. Med J Islam Repub Iran. 2015;29(1):312317.

3. Etemadi A, Mostafaei S, Yari K, Ghasemi A, Minaei Chenar H, Moghoofei M. Detection and a possible link between parvovirus B19 and thyroid cancer. Tumour Biol. 2017;39(6):1-7.

4. Tavakoli A, Monavari SH, Mollaei H, Bokharaei-Salim F, Esghaei M, Keyvani H, et al. Frequency of human Parvovirus B19 among patients with respiratory infection in Iran. Med J Islam Repub Iran. 2018;32(1):220-223.

5. Barah F, Whiteside S, Batista S, Morris J. Neurological aspects of human parvovirus B19 infection: a systematic review. Rev Med Virol. 2014;24(3):154-168.

6. Mishra B, Malhotra P, Ratho RK, Singh MP, Varma S, Varma N. Human parvovirus B19 in patients with aplastic anemia. Am J Hematol. 2005;79(2):166-167.

7. Kawakami C, Kono Y, Inoue A, Takitani K, Ikemoto T, Tamai H. Severe bone marrow failure associated with human parvovirus B19 infection in a case with no underlying disorder. Int $\mathrm{J}$ Hematol. 2012:1-2

8. Florea AV, Ionescu DN, Melhem MF. Parvovirus B19 infection in the immunocompromised host. Arch Pathol Lab Med. 2007;131(5):799-804.

9. Javanmard D, Ziaee M, Ghaffari H, Namaei MH, Tavakoli A, Mollaei H, et al. Human parvovirus B19 and parvovirus 4 among Iranian patients with hemophilia. Blood Res. 2017;52(4):311-315.

10. Tavakoli A, Karbalaie Niya MH, Keshavarz M, Ghaffari H, Asoodeh A, Monavari SH, et al. Current diagnostic methods for HIV. Future Virol. 2017;12(3):141-155.

11. Jahanbakhsh F, Ibe S, Hattori J, Monavari SHR, Matsuda M, Maejima M, et al. Molecular epidemiology of HIV type 1 infection in Iran: genomic evidence of CRF35_AD predominance and CRF01_AE infection among individuals associated with injection drug use. AIDS Res Hum Retroviruses. 2013;29(1):198-203.

12. Jahanbakhsh F, Hattori J, Matsuda M, Ibe S, Monavari SHR, Memarnejadian A, et al. Prevalence of transmitted HIV drug resistance in Iran between 2010 and 2011. PloS One. 2013;8(4):e61864.

13. Maracy MR, Mostafaei S, Moghoofei M, Mansourian M. Impact of HIV risk factors on survival in Iranian HIV-infected patients: A Bayesian approach to retrospective cohort. HIV AIDS Rev. 2017; 16(2):100-106.

14. Spivak JL, Bender BS, Quinn TC. Hematologic abnormalities in the acquired immune deficiency syndrome. Am J Med. 1984;77(2):224228 .

15. Zon LI, Arkin C, Groopman JE. Haematologic manifestations of the human immune deficiency virus (HIV). $\mathrm{Br} \mathrm{J}$ Haematol. 1987;66(2):251-256.

16. Clarke J, Lee J. Primary human parvovirus B19 infection in an HIV infected patient on highly active antiretroviral therapy. Sex Transm Infect. 2003;79(4):336.

17. Musiani M, Zerbini M, Gentilomi G, Rodorigo G, De Rosa V, Gibellini D, et al. Persistent B19 parvovirus infections in hemophilic HIV-1 infected patients. J Med Virol. 1995;46(2):103-108.

18. Zuckerman M, Williams I, Bremner J, Cohen B, Miller R. Persistent anaemia in HIV-infected individuals due to parvovirus B19 infection. Aids. 1994;8(8):1191-1192.

19. Gyllensten K, Jorup-Rönström C, Halvarsson M, Sönnerborg A, Yun Z. Parvovirus B19 infection in HIV-1 infected patients with anemia. Infection. 1994;22(5):356-358.

20. Chernak E, Dubin G, Henry D, Naides SJ, Hodinka RL, MacGregor $\mathrm{RR}$, et al. Infection due to parvovirus B19 in patients infected with human immunodeficiency virus. Clin Infect Dis. 1995;20(1):170-173.

21. Toppinen M, Norja P, Aaltonen L-M, Wessberg S, Hedman L, Söderlund-Venermo $\mathrm{M}$, et al. A new quantitative PCR for human parvovirus B19 genotypes. J Virol Methods. 2015;218:40-45.

22. Young NS, Brown KE. Parvovirus B19. N Engl J Med. 2004;350(6):586-597.

23. Cohen B, Buckley MM. The prevalence of antibody to human parvovirus B 19 in England and Wales. J Med Microbiol.
1988;25(2):151-153.

24. Kelly H, Rae P, Donnelly J, Leydon J. Fifth disease in a small rural community. What are the consequences? Aust Fam Physician. 1999;28(2):139-144.

25. Valeur-Jensen AK, Pedersen CB, Westergaard T, Jensen IP, Lebech M, Andersen PK, et al. Risk factors for parvovirus B19 infection in pregnancy. Jama. 1999;281(12):1099-1105.

26. Letalef M, Vanham G, Boukef K, Yacoub S, Muylle L, Mertens G. Higher prevalence of parvovirus B19 in Belgian as compared to Tunisian blood donors: differential implications for prevention of transfusional transmission. Transfus Sci. 1997;18(4):523-530.

27. Musiani M, Azzi A, Zerbini M, Gibellini D, Venturoli S, Zakrzewska K, et al. Nested polymerase chain reaction assay for the detection of B19 parvovirus DNA in human immunodeficiency virus patients. J Med Virol. 1993;40(2):157-160.

28. Kurtzman G, Frickhofen N, Kimball J, Jenkins DW, Nienhuis AW, Young NS. Pure red-cell aplasia of 10 years' duration due to persistent parvovirus B19 infection and its cure with immunoglobulin therapy. N Engl J Med. 1989;321(8):519-523.

29. Koch WC, Massey G, Russell CE, Adler SP. Manifestations and treatment of human parvovirus B19 infection in immunocompromised patients. J Pediatr. 1990;116(3):355-359.

30. Frickhofen N, Abkowitz JL, Safford M, Berry JM, Antunez-deMayolo J, Astrow A, et al. Persistent B19 parvovirus infection in patients infected with human immunodeficiency virus type 1 (HIV-1): a treatable cause of anemia in AIDS. Ann Intern Med 1990;113(12):926-933

31. Gottlieb F, Deutsch J. Red cell aplasia responsive to immunoglobulin therapy as initial manifestation of human immunodeficiency virus infection. Am J Med. 1992;92(3):331-333.

32. Ozawa K, Kurtzman G, Young N. Replication of the B19 parvovirus in human bone marrow cell cultures. Science. 1986;233(4766):883886.

33. Zhang L, Cai C, Pan F, Hong L, Luo X, Hu S, et al. Epidemiologic study of human parvovirus B19 infection in East China. J Med Virol. 2016;88(7):1113-1119.

34. Azadmanesh K, Mohraz M, Kazemimanesh M, Aghakhani A, Foroughi M, Banifazl M, et al. Frequency and genotype of human parvovirus B19 among Iranian patients infected with HIV. J Med Virol. 2015;87(7):1124-1129.

35. He M, Zhu J, Yin H, Ke L, Gao L, Pan Z, et al. Human immunodeficiency virus/human parvovirus B19 co-infection in blood donors and AIDS patients in Sichuan, China. Blood Transfus. 2012;10(4): 502-514.

36. Crabol Y, Terrier B, Rozenberg F, Pestre V, Legendre C, Hermine $\mathrm{O}$, et al. Intravenous immunoglobulin therapy for pure red cell aplasia related to human parvovirus b19 infection: a retrospective study of 10 patients and review of the literature. Clin Infect Dis. 2012;56(7):968977. 